\title{
Study on Effectiveness of Ideological and Political Education Based on Field Theory
}

\author{
Qing Wu, Hongjuan Ding \\ Shanghai University of Engineering Science, Shanghai 201620, China
}

\begin{abstract}
The occurrence of field concept and maturity of field theory open up a new research perspective and provide theoretical support for conduct of college ideological and political work. Combination of field theory with ideological and political work can integrate resources effectively and help enhance college ideological and political teaching quality. Based on this, this paper establishes a new sound ideological and political work system from the perspective of innovation and sets up a characteristic ideological and political work evaluation system, and thus lays a solid theoretical foundation for improving effectiveness of college ideological and political work.
\end{abstract}

Key words: colleges, ideological and political work, field theory, effectiveness

Ideological and political education is a main way to improve students' ideological and political level, and good effectiveness has been a teaching goal that ideological and political workers hope to achieve. At present, lots of theoretical exploration achievements have been made in effectiveness of ideological and political work, but there are still many difficulties in teaching. Thus, we shall deepen research on this topic, so as to better solve problems in ideological and political teaching. This paper combines ideological and political education with field theory and analyzes the effectiveness of ideological and political work.

\section{About ideological and political field}

\section{Concepts related to field}

Field theory is one of important concepts in academic thoughts of Bourdieu who was a famous sociologist in contemporary France. He thought that a differentiated society was not a machine suppressed under a common social overall logic or a self-organization with independent but systematic functions, but was consisting of a variety of relatively independent game fields, each of which was an objective relationship space with its own rules, logic and inevitability.

The background under which ideological and political work is combined with field theory 
is not simple: firstly, field theory takes root and sprouts rapidly after being introduced to China, which provides a new perspective and lays a solid theoretical foundation for study on Chinese ideological and political work; and secondly, after entering the new century, Chinese ideological and political work encounters a greater challenge as some stubborn problems always reappear after being solved, which is a difficulty in Chinese ideological and political work and on the other hand finds an appropriate entry point for intervention of field theory.

Currently, some problems in ideological and political work for Chinese college students shall be concerned: firstly, "emphasis on real objects instead of soft ones", which means too much attention to enhancement of professionalism of teaching materials and improvement of teaching facilities in ideological and political work while insufficient importance attached to ideological and political working mechanism and creation of campus cultural atmosphere; secondly, "emphasis on design instead of implementation", which means blindly pursuing teaching design and merely focusing on formulation and hierarchy of teaching goals in ideological and political work instead of being concerned about whether these goals conform to characteristics of students' psychological development and the school, as a result, it would be difficult to achieve teaching goals eventually in the long run and there would be only some anti-climax forms at most during teaching; thirdly, "emphasis on subjects instead of coverage", which means that some colleges put all energy into classes of ideological and political education during ideological and political work, hold an indifferent attitude towards some educational resources in the society, and fail to integrate effective force of these resources actively and initiatively to empower ideological and political work; and fourthly, "emphasis on potential energy instead of kinetic energy", or emphasis on policy-making instead of policy implementation, which means formulating a lot of seemingly effective policies vigorously without follow-up investigation of implementation effects of policies. Therefore, the low-efficiency state of ideological and political work cannot be effectively improved.

\section{Characteristics of ideological and political education field}

(1) Ideological and political education field has its own nature, and has a cross structure and mutually influencing logical relationship like other fields. With a subject-object relationship structure established under interaction between education doctrine and education objects, it is a combination of contradictions. Mutual cross and influence between education subjects and 
objects promote continuous development of this field and none of education subjects or objects would exist without each other. Meanwhile, it is mutual confliction and influence between both of them that compose mutual internal connection or form a law of field. Education subjects and objects stick to their respective positions in this field, and unique behavioral patterns and thinking habits are gradually formed between education subjects and topics.

(2) Ideological and political education field is a contradiction and a space built during mutual influence of education subjects and customers. Ideological and political education mainly aims at improving students' ideological and moral level and promoting students to have good accomplishment in future learning and even work. Ideological and political education field is full of contradictions during interaction between education subjects and objects, and has a very unharmonious establishment process, but finally becomes a harmonious community gradually through mutual influence of these factors. It should be noted that we shall firstly ensure correct direction of ideological and political work and guarantee that educators always hold a dominant position and play a leading role in field in order to reach this goal and solve contradictions within the field. Under attention of field, the relationship between education subjects and objects and their positions are allocated by possessors of educational resources and cultural capital, and position switching between them i.e. the result of field activity denotes final effects of ideological and political education within this field. 


\section{Strategies established in college ideological and political work field}

\section{Establish and perfect operating mechanism of ideological and political work field}

To establish ideological and political work field system, two aspects of foundation shall be laid, namely external extension and rationalizing of internal relationship. "External extension" is mainly to establish an ideological and political work coordination system among fields. Colleges, party committees, relevant government departments and other related social forces could give play to their strength in establishment of college ideological and political education system, set up a joint conference system, carry out collective discussion regularly about ideological changes of college students, establishment of education practice working platform, and conduction of large-scale teaching activities etc, and form a normalized and systematic collaborative discussion system. These aspects of work can be completed under guidance of Party Committee Publicity Department and sponsoring of colleges. Relevant departments could carry out statistics and calculation of required budget, put forward a number of effective measures such as college student growth social public welfare fund etc, establish a spending system beyond campus, fields and even regions, and perfect guarantee system in terms of site and faculty etc. "Internal rationalizing" means to adjust relationships among internal factors of field, centralize forces of all factors to a maximum degree, and enhance effectiveness of ideological and political work.

Colleges shall coordinate all forces, strengthen coordination of relevant departments such as teaching, scientific research and social communities etc, gather all aspects of forces including construction of ideological and political classes, college scientific and technological change activities, progress of scientific research, and construction of campus culture etc, and establish a stable and interdisciplinary ideological and political work collaborative system. Besides, colleges shall establish an "all-round education" system of the new era through top planning, make clear responsibilities and rights of relevant departments and all links, and set up a cross-subject operating system within the field with basic orientation of improving teaching and operating effects. For example, joint efforts of all aspects are required in conduction of large-scale theme educational activities, activity operation of relevant organizational departments and establishment of a highly effective ideological and political work operation support system etc. In this context, we shall coordinate all aspects, strive to normalize rules 
related to ideological and political construction, operate mechanisms and systems of work related to all fields, and establish highly effective ideological and political work self-running system etc.

\section{Promote connection among subjects}

Marxism tells that connection runs through the entire development course of things, and issues related to ideological and political education field of higher colleges shall also be viewed from the perspective of connection. The largest connection in field of ideological and political education of higher colleges lies among subjects. All subjects exchange each other's ideological and political state through ideological and political activities and then establish sound political thoughts. However, higher colleges shall provide students with different fields of ideological and political activities, which shall include activities in language field, spiritual field and material field, so as to carry out ideological and political education for subjects. All different subjects attend activities through "subject-object-subject" activity mechanism. In this way, the relationship between education objects and educators is not traditional classroom education relationship, i.e. changes from traditional educators-education objects into educators-education objects, then education objects-educators, and finally spread between education subjects-education subjects, through which ideological and political educational activities are completed and better effects of ideological and political education can be reached.

So, connect subjects of ideological education by theory of connection, and integrate ideological education field with daily education and teaching work. Only in this way, can value created through activities among subjects be given better play to and can ideological and political education of higher colleges be promoted to a certain height. Meanwhile, in this context, higher colleges with ideological and political education shall summarize the law of teaching effects presented under new educational environment and new teaching methods, and then help future ideological and political education. Moreover, higher colleges shall also attach importance to the position of subjects and relationship among subjects, so as to establish a teaching relationship which is conducive to education between educators and education objects and complete ideological and political education of higher colleges.

\section{Establish a specialized ideological and political evaluation mechanism}

System evaluation mechanism plays the most important functions of resource regulation 
and value guidance. During evaluation construction, simple emphasis on goal management at the beginning shall be gradually transformed into goal management and process management in order to realize innovative evaluation methods. Ideological and political workers shall have knowledge transfer ability and profound cultural deposits as well as quite distinctive cultural integration ability, so that transformation could be carried out smoothly. During field construction, investigation shall be conducted in terms of not only effectiveness enhanced through collaborative innovation ability, resource sharing and overall qualities of college students etc, but also effects achieved by using innovative concepts and methods during regional construction, instead of taking merely short-term performance as investigation and evaluation basis. Besides, traditional higher college ideological and political education can be reformed into that in line with the new era through new field.

To fully achieve an innovative way of innovation evaluation standards, hierarchical evaluation standards and measures shall be established according to circumstances. For instance: during field construction, investigate fundamental equipment of system and hardware measures etc, and whether field construction and organizational operation play an innovation-driven role in college ideological and political work etc. During ideological and political work evaluation, attitudes towards work such as "sensationalism" and "fuzzy theory" shall be avoided, and effects achieved at all levels and stages of ideological and political engineering shall be truly reflected. Innovative evaluation concept changes previous conventional operating modes, changes rigid working concepts to a certain degree, attaches importance to regulations, movements and investigation of effects, and promotes exploration of differentiated, related and solid evaluation modes from many aspects etc. So, strengthen characteristic specialized projects for evaluation of shares in overall weight. Colleges shall give real evaluation of teaching and innovation during field construction according to actual situation of colleges and work related to establishment of differentiated ideological and political construction brand.

\section{Establish a public opinion field with a spiritual education atmosphere}

Publicity and public opinion are a type of cultural restraint under which education functions normally. College publicity departments, students' affairs offices, youth league committees and other related departments shall not only carry out school spiritual education 
publicity activities by making use of their advantages, including publicity of school spirit through campus websites and bbs etc, but also strengthen monitoring and management of campus websites and bbs etc, enhance source management of online public opinions, increase efforts in positive guidance for students and try to establish a clear and healthy public opinion environment.

\section{Conclusions}

Construction of working field plays a very important role in ideological and political education of higher colleges, and new educational concepts and carriers can be provided for ideological and political education of higher colleges by establishing a new field. Higher colleges shall follow closely innovation of ideological and political education content at the same time with innovation of ideological and political educational patterns. Only in this way, can effects of working field construction and higher college ideological and political education of the new era be really given play to, so as to cultivate qualified talents for the country.

\section{Acknowledgments}

This paper serves as the following foundation projects:

1. Project of Student Work Research Branch of Chinese Association of Higher Education (LX2014Y082);

2. 2014 Ideological and Political Work Research Conference Research Project of Shanghai University of Engineering Science "Study on Interactive Mechanism between College Student Party Building and Ideological and Political Education Based on Theory of Collaboration" (2014GSZ05);

3. Party Building Research Project of Shanghai University of Engineering Science "Study on Student Party Building Pattern in the Context of Full Credit System".

\section{References:}

[1] Zhang Yaocan, Liu Wei. Preliminary Exploration of Connotation of Ideological and Political Education Inter-subjectivity [J]. School Party Building and Ideological Education, 2006, (12): 8-9. [2] Guo Hua. "Competition and Fight for Authentication and Management Right of Judicial Field-With the Center of 'Decision on Judicial Authentication and Management Issues' by the Standing Committee of the National People's Congress" [J]. Journal of the East China University 
of Politics \& Law, 2005, (05): 12-13.

[3] Written by Pierre Bourdieu [France] and Translated by Hua Kangde, Li Meng, Li Kang et al. Practice and Reflection [M]. Beijing: Central Compilation \& Translation Press,1988: 133-134.

[4] Written by Bourdieu [France] and Translated by Chen Shengsheng, Tu Shiwen, Liang Yahong et al. The Science of Science and Its Reflexivity-Special Lecture of Institute of France (2000-2001 Academic Year) [M]. Guilin: Guangxi Normal University Press, 2006: 25-26.

[5] Yao Lin. Unconscious Education: under the Network Environment of Ideological and Political Education Strategies [J]. Journal of Shijiazhuang Railway Institute (Social Sciences). 2011 (02): 112-115.

[6] Liang Jianfei. On Problems in College Network Ideological and Political Education of the New Era and Countermeasures [J]. Economic Research Guide. 2012 (09): 58-59. 